\title{
Phytochemical analysis and in-vitro antimicrobial screening of the leaf extract of Senna occidentalis (Fabaceae)
}

\author{
A.A. TAMASI ${ }^{1}$, M.O. SHOGE ${ }^{1, \boldsymbol{\varphi}}$, T.T. ADEGBOYEGA ${ }^{2}$, E.C. CHUKWUMA ${ }^{3}$ \\ ${ }^{1}$ Department of Chemistry, Faculty of Science, Air Force Institute of Technology, PMB 2014, Nigerian Air Force Base, Kaduna, Kaduna State, Nigeria. \\ vemail: moshachemist@yahoo.com,m.shoge@afit.edu.ng \\ ${ }^{2}$ Biology Unit, Faculty of Science, Air Force Institute of Technology, PMB 2014, Nigerian Air Force Base, Kaduna, Kaduna State, Nigeria \\ ${ }^{3}$ Forest Herbarium Ibadan, Forestry Research Institute of Nigeria. Jericho Hills, Ibadan, Oyo State, Nigeria
}

Manuscript received: 25 February 2021. Revision accepted: 31 August 2021.

\begin{abstract}
Tamasi AA, Shoge MO, Adegboyega TT, Chukwuma EC. 2021. Phytochemical analysis and in-vitro antimicrobial screening of the leaf extract of Senna occidentalis (Fabaceae). Biofarmasi J Nat Prod Biochem 19: 58-65. Due to the use of Senna occidentalis as an antimalarial, anti-inflammatory, antioxidant, hepatoprotective, and antibacterial agent, traditionally, this study examined the phytochemical composition and antimicrobial activity of the isolated methanol, ethyl acetate, and hexane fractions of the leaves of Senna occidentalis. Qualitative and quantitative phytochemical analyses were carried out using standard procedures. Antimicrobial activity was performed by using standard procedures against known common clinical isolates. Qualitative phytochemical analysis showed the abundance of saponins, tannins, flavonoids, and terpenoids in the ethyl acetate fraction. Cardiac glycosides were not detected in all the tested isolated fractions, while steroids were present and abundant in ethyl acetate and hexane fractions, respectively. Quantitative phytochemical analysis showed that the methanol fraction contained $4 \% \mathrm{w} / \mathrm{w}$ alkaloids, $0.51 \% \mathrm{w} / \mathrm{w}$ flavonoids, $9.5 \% \mathrm{w} / \mathrm{w}$ saponins, $1.3 \% \mathrm{w} / \mathrm{w}$ tannins, $5.5 \% \mathrm{w} / \mathrm{w}$ terpenoids, and $0.6 \% \mathrm{w} / \mathrm{w}$ total phenol content. The antimicrobial susceptibility test shows a range of inhibitory zone of 10-16 mm. Hexane fraction has the highest zone of inhibition against Candida albicans. The lowest MIC values of $0.6 \mathrm{mg} / \mathrm{mL}$ and $0.2 \mathrm{mg} / \mathrm{mL}$ were observed in ethyl acetate fraction against Candida albicans and Escherichia coli, respectively. The highest MIC was $20 \mathrm{mg} / \mathrm{mL}$ was observed in the ethyl acetate fraction against Staphylococcus aureus. The MMC values varied widely. The MMC value against Bacillus subtilis, Candida albicans, and Trichophyton rubrum was 5mg/mL, while the MMC value against Staphylococcus aureus, Pseudomonas aeruginosa, and Escherichia coli was $20 \mathrm{mg} / \mathrm{mL}$. The results from this study show that the leaves of Senna occidentalis can serve as a potential source of some phytochemicals and also have the potential to be developed as a source of antibiotics.
\end{abstract}

Keywords: Alternate medicine, antimicrobial, phytochemicals, Senna occidentalis

\section{INTRODUCTION}

Medicinal plants are traditionally used globally for treating many diseases, including but not limited to; asthma, gastrointestinal problems, skin disorders, respiratory and urinary problems, and hepatic and cardiovascular disease (Tian et al. 2014). Plants synthesize a wide range of biologically active compounds (Cushnie et al. 2014) that are important for them to survive and flourish in the natural environment, protecting them from abiotic stress, insect pests, as well as disease infections (Vardhini and Anjum 2015). Since medicinal plants possess an effective source of natural antimicrobial products with the proven potential to treat infectious diseases compared to the synthetic drug, there has been a gradual revival of interest in the use of medicinal plants in developed and developing countries (Akinyemi et al. 2006; Ajayi and Akintola 2010; Valarmathy et al. 2010). Natural products from medicinal plants are used in pharmaceutical preparations either as pure or as extracts (Gogtay et al. 2002).

Senna is a large genus of flowering plants in the legume family, Fabaceae (Leguminosae). This genus is distributed throughout the tropics comprising more than
300 species (Gebrelibanos et al., 2014). Senna species are commonly used as ornamentals and famine foods, and many species are used in both traditional and modern medicines (Haraguchi et al. 1998). Senna occidentalis (L.) Link. (Syn. Cassia occidentalis L.) is commonly known as coffee Senna (Odeja et al. 2014). It is found in open pastures and fields, cultivated with cereals such as soybean, corn, sorghum, and others (Barbosa-Ferreira et al. 2005). Various parts of $S$. occidentalis (seeds, roots, leaves, and stems) are traditionally claimed to be useful in treating different medical conditions and infections (Bekele and Reddy, 2015). It has been used as a folklore medicine for hepatotoxicity treatment. The aqueous-ethanolic leaves extract was tested for hepatoprotective activity on liver damage in paracetamol-induced hepatotoxicity in rats, showing that the paracetamol-induced hepatotoxic indications were to some degree reduced after 21 days of treatment with Senna occidentalis leaves extract in a dosedependent manner (Uzzi and Grillo 2013). Aqueous extract of Senna occidentalis tested for antidiabetic activity showed a significant reduction in fasting blood glucose levels in the normal and alloxan-induced diabetic rats (Laxmi 2010). 
Previous studies on $S$. occidentalis extract in four different solvents (methanol, aqueous, benzene, petroleum ether, and chloroform) showed that methanol extract had antimicrobial activity against Pseudomonas aeruginosa, Klebsiella pneumoniae, Proteus mirabilis, Escherichia coli, Staphylococcus aureus, and Staphylococcus epidermidis. The aqueous extract was effective against Proteus vulgaris, Klebsiella pneumoniae, and Pseudomonas aeruginosa; In contrast, benzene and petroleum ether extracts were active against Proteus mirabilis and Escherichia coli, and chloroform extract was inactive against all tested strains (Arya et al. 2010). Further, a study by Daniyan et al. (2011) showed that flower extract of $S$. occidentalis had maximum inhibition against Klebsiella pneumoniae and no activity against Staphylococcus aureus, Streptococcus pneumoniae, and Pseudomonas aeruginosa. Thus, the flower extract of S. occidentalis can be used to treat Klebsiella-associated ailments such as pneumonia, bronchitis, and other diseases caused by Klebsiella pneumonia.

The antibacterial and antimalarial activities of this plant's leaves and root bark extracts have also been reported (Tona et al., 2001; Chukwujekwu et al., 2006). Studies on the ethanolic, dichloromethane, and lyophilized aqueous extracts of $S$. occidentalis root bark were tested for antimalarial activity against Plasmodium berghei. When administered orally to experimental animals (mice), the extracts produced significant chemo suppressions of parasitemia with a $200 \mathrm{mg} / \mathrm{kg}$ dose. The species was found to be potential with $60 \%$ chemo suppression of the parasites.

Ibrahim et al. (2010) attempt to demonstrate the in vitro and in vivo activities of $S$. occidentalis against Trypanosoma bruce. Although the exact mechanism for the observed in vivo trypano-suppressive effect is not known, it is obvious that the extract contains some phytochemicals that could interfere with the survival of the parasites in vivo. The presence of alkaloids, flavonoids, tannins, and anthraquinones have been reported in this extract (Ogunkunle and Ladejobi 2006), and previous reports attributed the antitrypanosomal activity of several tropical plants to the flavonoids (azaanthraquinone), highly aromatic planar quaternary alkaloids, barbarine and harmaine (Nok 2001). The trypanosuppressive action of this extract could be due to the presence of one or more of these bioactive compounds. The present study examined the phytochemical compounds of $S$. occidentalis leaves which could be useful for synthesizing conventional drugs and their antimicrobial activity.

\section{MATERIALS AND METHODS}

\section{Sample collection and preparation}

The plant was collected at Unguwar Dosa, Kaduna, Nigeria, and identified by Prof Gabriel Ajibade of the Biological Sciences Department, Nigerian Defence Academy, Kaduna. It was authenticated at the Forest Herbarium Ibadan (FHI) (Holmgren et al. 1990). Upon collection, the plant leaves were rinsed with distilled water, air-dried at room temperature for two weeks, and then blended into fine powder. Active compounds from the plant were extracted in a crude form through a cold maceration extraction method using methanol for 72 hours, concentrated at $40^{\circ} \mathrm{C}$ using a rotary evaporator, and the crude extract was fractionated with hexane, ethyl acetate, and methanol successively in a $500 \mathrm{ml}$ separating funnel.

Figure 1.0 illustrates the morphology of S. occidentalis, while Figure 2 shows the species' current distribution in Nigeria.

\section{Qualitative phytochemical screening}

The hexane, ethyl acetate, and methanol fractions of $S$. occidentalis were assessed for the existence of some phytochemicals using the following standard methods:

\section{Test for Alkaloids}

(i) Dragendroff's reagent: $8 \mathrm{~g}$ of $\mathrm{Bi}\left(\mathrm{NO}_{3} .5 \mathrm{H}_{2} \mathrm{O}\right)$ was dissolved in $20 \mathrm{ml}$ of nitric acid and $2.72 \mathrm{~g}$ of potassium iodide in $50 \mathrm{ml}$ of water, mixed and makeup to $100 \mathrm{ml}$ with distilled water.

Test: To $0.1 \mathrm{~g}$ of extract, add $2.0 \mathrm{ml}$ of $\mathrm{HCl}$. To this acidic medium, $1 \mathrm{ml}$ of reagent was added. An orange-red precipitate produced immediately indicates the presence of alkaloids.

(ii) Wagner's reagent: $1.0 \mathrm{~g}$ of iodine and $2.0 \mathrm{~g}$ of potassium iodide were dissolved in $5 \mathrm{ml}$ sulphuric acid, diluting the solution to $100 \mathrm{ml}$.

Test: $0.1 \mathrm{~g}$ extract was acidified by adding $1.5 \% \mathrm{v} / \mathrm{v}$ $\mathrm{HC} 1$ and a few drops of Wagner's reagent. The formation of yellow or brown precipitate confirmed the presence of alkaloids.

(iii) Meyer's reagent:1.36 g Mercuric chloride was dissolved in $60 \mathrm{ml}$ of distilled water and $5 \mathrm{~g}$ of potassium iodide in $10 \mathrm{ml}$ of water. The two solutions were mixed and diluted to $100 \mathrm{ml}$ with distilled water.

Test: To $0.1 \mathrm{~g} \mathrm{ml}$ of extract, a few drops of reagent were added. The formation of white or pale precipitate showed the presence of alkaloids.

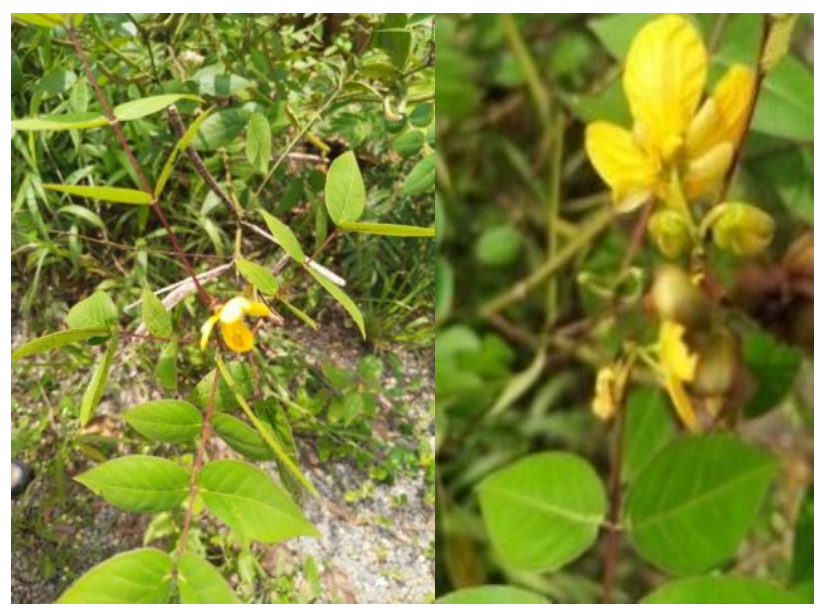

Figure 1. Morphology of Senna occidentalis (L.) Link. 


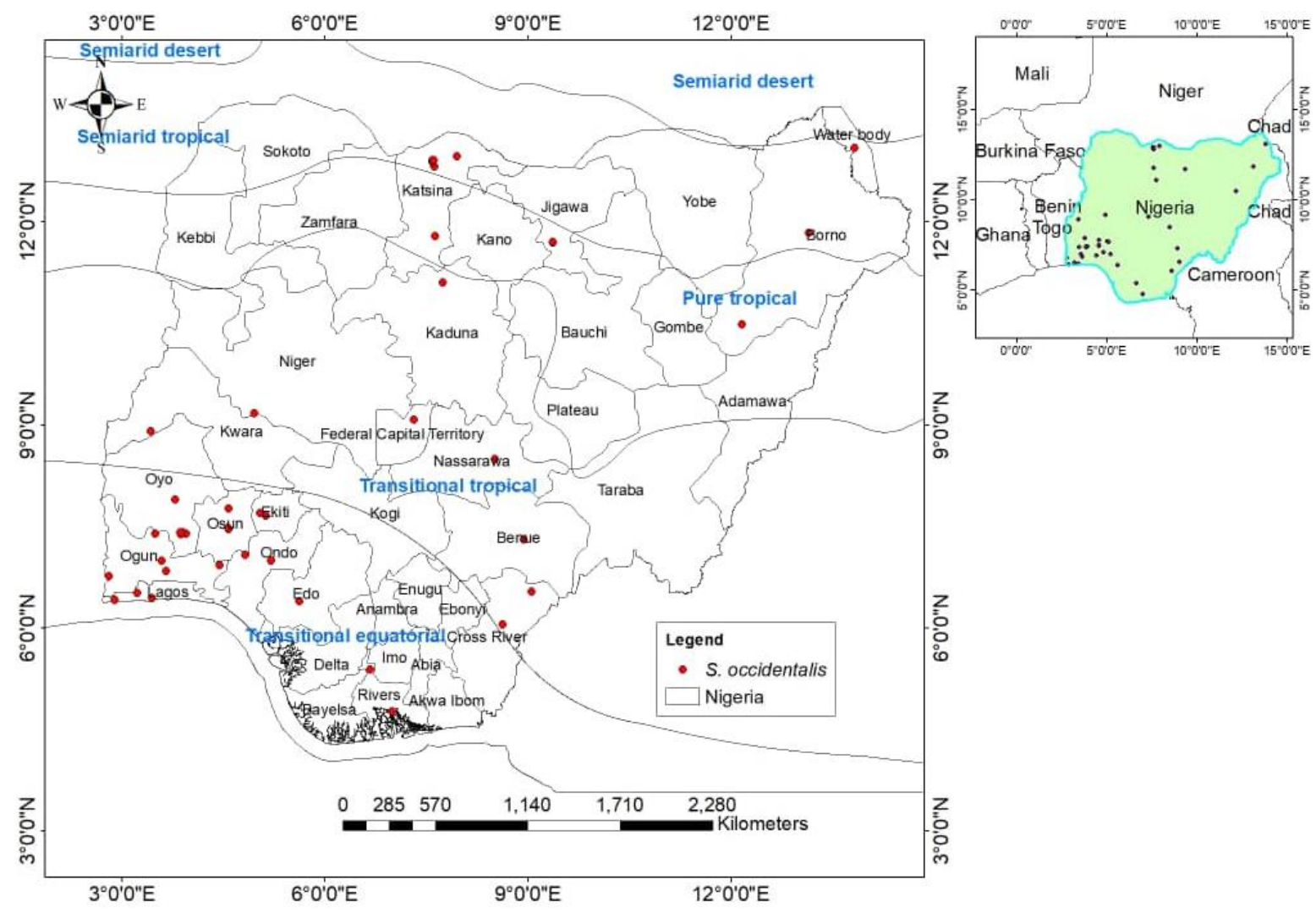

Figure 2. Distribution of S. occidentalis in Nigeria

Test for flavonoids: ammonia/ $\mathrm{H}_{2} \mathrm{SO}_{4}$

The sample was added to $5 \mathrm{ml}$ of diluted ammonia solution and concentrated $\mathrm{H}_{2} \mathrm{SO}_{4}$. The disappearance of yellow color on standing indicates the presence of flavonoids.

\section{Test for saponins: Frothing Test}

$3 \mathrm{ml}$ of the aqueous solution of the extract was mixed, stoppered in a test tube, shaken vigorously for about 30sec, then allowed to stand for $3 \mathrm{~min}$ and observed for a persistent honeycomb froth, which indicates the presence of saponins.

\section{Test for tannins: Ferric chloride method}

$2 \mathrm{ml}$ of the aqueous extract was added to 3 drops of $10 \%$ Ferric chloride solution. The occurrence of blue-black color showed the presence of tannins

\section{Anthraquinone test: Borntrager's test}

$0.1 \mathrm{~g}$ of the dried extract was placed in a dry test tube, and $5 \mathrm{ml}$ of chloroform was added and heated in a steam bath for $1 \mathrm{~min}$. The extract was filtered while hot and allowed to cool. A $10 \%$ ammonia solution was added to the filtrate and then shaken. The upper aqueous layer was observed for bright pink, indicating the presence of anthraquinones.

\section{Terpenoids test: Salkowski test}

$0.1 \mathrm{~g}$ of the sample was mixed with $2 \mathrm{ml}$ of $\mathrm{CHCl}_{3}$ in a test tube $3 \mathrm{ml}$ of concentrated $\mathrm{H}_{2} \mathrm{SO}_{4}$ was carefully added to the mixture to form a layer. An interface with a reddishbrown coloration was formed if the terpenoid constituent was present.

\section{Cardiac glycosides Test: Keller-Killiani test}

A solution of glacial acetic acid $(4.0 \mathrm{ml})$ with 1 drop of $2.0 \% \mathrm{FeCl}_{3}$ was mixed with $10 \mathrm{ml}$ aqueous plant extract and $1 \mathrm{ml}$ concentrated $\mathrm{H}_{2} \mathrm{SO}_{4}$. A brown ring formed between the layers showed the presence of cardiac glycosides.

\section{Phenol test: Ferric chloride test}

Each $1 \mathrm{ml}$ aliquot of each fraction was added with 3-4 drops of neutral $5 \%$ ferric chloride solution. The formation of dark green color indicated the presence of phenols.

\section{Steroids test: Liebermann-Burchard test}

The extracts were added $5 \mathrm{ml}$ of chloroform, shaken, and filtered. Then a few drops of acetic anhydride along with a few drops of concentrated sulphuric acid were added through the side of the tube. The appearance of green color indicates the presence of sterols in the extracts. 


\section{Quantitative phytochemical screening}

Quantitative determination of alkaloids

Quantitative determination of alkaloids was performed according to the phytochemical methods described by Harborne (1973). Exactly $200 \mathrm{~cm}^{3}$ of $10 \%$ acetic acid in ethanol was added to each fraction $(1 \mathrm{~g})$ in a $250 \mathrm{~cm}^{3}$ beaker and allowed to stand for 4 hours. The fractions were concentrated on a water bath to $1 / 4$ of their original volume, and $10 \mathrm{ml}$ of concentrated ammonium hydroxide was added until the precipitation was complete and filtered after 3 hours with a pre-weighed filter paper. The residues were dried in an oven, and the percentage of alkaloid for each fraction was calculated mathematically as follows:

$$
\% \text { Alkaloids }=\frac{\text { Weight of alkaloid }}{\text { Weight of samples }} 100
$$

\section{Quantitative determination of terpenoids}

Dried plant extracts (1g) of each fraction (Wi) were soaked in $20 \mathrm{ml}$ of ethanol for 24 hours (Indumathi et al., 2014). After filtration, the extracts were extracted with 10 $\mathrm{ml}$ of petroleum ether using a separating funnel. The ether extract was separated into pre-weighed glass vials and kept completely dry (Wf). The formula measured the yield $(\%)$ of total terpenoids contents:

$$
\% \text { Terpenoids }=\frac{\mathrm{Wi}-\mathrm{Wf}}{\mathrm{Wi}} \times 100
$$

\section{Quantitative determination of saponins}

Quantitative determination of saponins was carried out using the method by Ejikeme et al. (2014). $100 \mathrm{~cm}^{3}$ of $20 \%$ aqueous ethanol was added to $1 \mathrm{~g}$ of each fraction in $250 \mathrm{~cm}^{3}$ conical flasks. The mixtures were heated over a hot water bath for 4 hours with continuous stirring at a temperature of $55^{\circ} \mathrm{C}$. The residue of the mixtures was reextracted with another $100 \mathrm{~cm}^{3}$ of $20 \%$ aqueous ethanol after filtration and heated for 4 hours at a constant temperature of $55^{\circ} \mathrm{C}$ with constant stirring. The extracts were evaporated to $40 \mathrm{~cm}^{3}$ over a water bath at $90^{\circ} \mathrm{C}$. $20 \mathrm{~cm}^{3}$ of diethyl ether was added to the concentrate in a $250 \mathrm{~cm}^{3}$ separating funnel and vigorously agitated, from which the aqueous layer was recovered while the ether layer was discarded. This purification process was repeated twice. $40 \mathrm{~cm}^{3}$ of $\mathrm{n}$-butanol was added to the aqueous portion, shaken, and allowed to partition. The butanol layer was collected after $10 \mathrm{~min}$. this process was repeated twice, and the combined butanol layer was washed with $20 \mathrm{~cm}^{3}$ of $5 \%$ sodium chloride and heated in a pre-weighed crucible. The saponin content was calculated as follows:

$$
\% \text { Saponins }=\frac{\text { Weight of saponins }}{\text { Weight of samples }} \times 100
$$

\section{Quantitative determination of tannin (using the spectrophotometric method)}

Tannins contents were quantitatively determined by the Folin-Ciocalteau method for ethyl acetate and methanol fractions. $0.1 \mathrm{ml}$ of each fraction were added to volumetric flasks $(10 \mathrm{ml})$, both containing $7.5 \mathrm{ml}$ of distilled water and
$0.5 \mathrm{ml}$ of Folin-Ciocalteu phenol reagent, and $1 \mathrm{ml}$ of $35 \%$ $\mathrm{Na}_{2} \mathrm{CO}_{3}$ solution was diluted to $10 \mathrm{ml}$ with distilled water. The mixtures were shaken well and kept at room temperature for 30 minutes. Reference standard solutions of gallic acid $(32,63,125,250,500$, and $1000 \mu \mathrm{g} / \mathrm{mL})$ were prepared. Absorbance for test and standard solutions were measured against the blank at $760 \mathrm{~nm}$ with a UV/Visible spectrophotometer (Miean and Mohamed 2001; Ribarova and Atanassova 2005).

\section{Determination of total flavonoid content}

Total flavonoid content was determined from the calibration curve of quercetin and expressed as a microgram of quercetin equivalent per milligram of extract. Total flavonoid content was determined according to the procedure of (Chang et al. 2002), validated by (Nugroho et al. 2013) with some modifications. $1 \mathrm{mg} / 1 \mathrm{ml}$ standard solution was prepared, and series concentrations of quercetin were then obtained. The sample solution $(0.5 \mathrm{ml})$ was added with $1.5 \mathrm{ml}$ methanol, $0.1 \mathrm{ml}$ of $10 \% \mathrm{AlCl}_{3}, 0.1$ $\mathrm{ml}$ Potassium acetate $1 \mathrm{M}$, and $2.8 \mathrm{ml}$ of distilled water and then incubated for 30 minutes. Absorbance was measured at $415 \mathrm{~nm}$. Distilled water was used as blank. Total flavonoid content was expressed in $\mathrm{mg}$ quercetin per $1 \mathrm{~g}$ of plant extract.

\section{Total phenolic content}

The total phenolic content of ethyl acetate and methanol extracts (200-1000 ug/mL) were quantified using the Folin -Ciocalteu's phenol reagent (Singleton and Rossi 1965) with gallic acid (50-200ug/mL) as standard. Each extract (1 $\mathrm{ml}$ ) was added to $1 \mathrm{ml}$ Folin-Ciocalteu 's reagent (diluted tenfold in distilled water) in separate test tubes. The content of each test tube was mixed and allowed to stand for five minutes at $25^{\circ} \mathrm{C}$ in an incubator. $1 \mathrm{ml}$ of $2 \%$ sodium carbonate solution $\left(\mathrm{Na}_{2} \mathrm{CO}_{3}\right)$ was added to the mixture. This was allowed to stand for 2 hours at $25^{\circ} \mathrm{C}$ in an incubator and centrifuged at $1000 \mathrm{~g}$ for 10 minutes to get a clear solution. The absorbance of the supernatant was then determined at $760 \mathrm{~nm}$ using a UV spectrophotometer. Distilled water $(1 \mathrm{ml})$ was added to $1 \mathrm{ml}$ Folin-Ciocalteu's reagent (diluted ten-fold in distilled water), processed in the same way as done for the test samples, and used as blank. All measurements were done in triplicates. The total phenolics were expressed as micrograms per milliliter of gallic acid equivalents through the calibration curve with gallic acid.

\section{Antimicrobial susceptibility test of Senna occidentalis}

Determination of antimicrobial activity by standard procedures

Isolates of micro-organisms were obtained from the Department of Pharmaceutical Microbiology, University of Ibadan, Nigeria. The antimicrobial activity of methanol, ethyl acetate, and hexane fractions of $S$. occidentalis was determined against Staphylococcus aureus, Bacillus subtilis, Pseudomonas aeruginosa, Escherichia coli, Candida albicans, and Trichophyton rubrum. A suspension of micro-organism pure culture by disk diffusion was spread evenly over the face of a sterile agar plate using a sterile swab. For all the fractions, $100 \mathrm{mg} / \mathrm{mL}$ and 50 
$\mathrm{mg} / \mathrm{mL}$ were applied to the center of the various agar plates (in a fashion that the antimicrobial didn't spread out from the center). Gentamicin, $10 \mathrm{ug} / \mathrm{mL}$, and $1 \%$ Ketoconazole were inoculated as controls. The agar plate was incubated for 24 hours at a temperature of $37^{\circ} \mathrm{C}$. The zone of inhibition appears when the plant extract fractions exert a growth-inhibiting effect. The diameter of the inhibitory zone was measured in millimeters and is related to the level of antimicrobial activity present in the fraction; the larger the inhibitory zone usually means, the better the antimicrobial potency.

\section{Determination of Minimum Inhibitory Concentration (MIC) \& Minimum Microbicidal Concentration (MMC) (Pramila et al. 2012)}

The minimal inhibitory concentration (MIC) is defined as the lowest compound concentration that inhibits the microorganisms' growth. Minimal bactericidal concentration (MBC) is defined as the lowest concentration of the compounds that kill and show no growth of the microorganisms on an agar plate. As previously described, the test microbes were grown in nutrient broth and potato dextrose broth for bacteria and fungus, respectively, and the cultures were adjusted to $0.5 \mathrm{McF}$ arland standard turbidity. MIC and MBC values of the plant extract against Staphylococcus aureus, Bacillus subtilis, Pseudomonas aeruginosa, Escherichia coli, Candida albicans, and Trichophyton rubrum were determined based on the microwell dilution method. The 24-well microtiter plates were prepared by dispensing $2 \mathrm{ml}$ of $\mathrm{MH}$ broth into each well and $3 \mu \mathrm{l}$ of the bacterial and fungal inoculum. The plant extract was dissolved in the fractions to obtain the concentration of $1 \mathrm{mg} / \mathrm{mL}$ and was serially diluted and mixed thoroughly. Then the plates were incubated at $37^{\circ} \mathrm{C}$ for $24 \mathrm{~h}$

\section{RESULTS AND DISCUSSION}

The screening of plant parts for medicinal properties starts with crude extract preparation using a range of solvents with different polarities to dissolve different phytochemicals compounds in the plant parts. This is a vital step in drug development from the plant. Phytochemical constituents vary quantitatively and qualitatively in different plant species and even in plant parts of the same species depending on various atmospheric conditions and storage conditions (Jahan et al. 2008). Three solvents (hexane, ethyl acetate, and methanol) were used for the extract preparation. The qualitative phytochemical screening of the three fractions is shown in Table 1.

Saponins and terpenoids were found to be present in all three extracts of $S$. occidentalis. Tannins, flavonoids, alkaloids, and phenols were found to be present in ethyl acetate, and methanol extracts only. Steroids and anthraquinones were positive in hexane and ethyl acetate extracts, while cardiac glycoside was completely negative in all three extracts.
The occurrence of this wide range of phytochemicals shows the medicinal potential of $S$. occidentalis. Alkaloids, saponins, tannins, flavonoids, and steroids have been biologically active, thus partially responsible for the antimicrobial activities of plants (Nethathe and Ndip, 2011). Flavonoids are known to be synthesized by plants in response to microbial infection (Cowan 1999); antimicrobial properties of saponins are due to the leakage of proteins and certain enzymes from the cell (Zablotowicz et al. 1996), while tannins are bound to proline-rich proteins and interfere with the protein synthesis (Shimada 2006).

As revealed in Table 2, the three fractions had a range of terpenoids from $5.5 \%$ to $7.5 \%$ w/w. Malik et al. (2017) also reported a wide range of terpenoid content, i.e., Cassia absus contains $40 \%$, and Carissa carandas $80 \%$, which were used as medicinal plants in Punjab. Terpenoids are chemically interesting groups of secondary metabolites (Ajaib et al. 2016) of important therapeutic use as antimicrobial, antifungal, antiviral, antihyperglycemic, anti-inflammatory, antioxidants, and antiparasitic (Brahmkshatriya and Brahmkshatriya 2013). Jaeger and Cuny (2016) reported that terpenoids are naturally formed in a stereospecific manner and can be obtained in enantiopure form by extraction from natural sources. Thus, the pure enantiomeric form is needed to produce highly active medical compounds of high pharmaceutical value.

Saponins have a wider range of $1.5 \%$ to $9.5 \% \mathrm{w} / \mathrm{w}$ across the tested fractions. A previous study by Ezeonu and Ejikeme (2016) also reported a wide range of saponin content between Protea elliottii (1.6\%) to Anogeissus leiocarpus $(12.5 \%)$. Extracting saponins from these plants serves as a good source of saponins since saponins protect plants against microbial attacks such as yeast and fungal infections (Sheikh et al., 2013). Oyekunle et al. (2006) reported that saponins show antimicrobial activity by inhibiting the growth of Gram-positive and Gram-negative microorganisms. However, some saponins are ineffective against Gram-negative microorganisms because saponins are not able to penetrate the cell membranes of Gramnegative bacteria.

Table 1. Phytochemicals compounds of three fractions of $S$. occidentalis leaves

\begin{tabular}{llll} 
Test & $\begin{array}{c}\text { Hexane } \\
\text { Fraction }\end{array}$ & $\begin{array}{c}\text { Ethyl acetate } \\
\text { Fraction }\end{array}$ & $\begin{array}{l}\text { Methanol } \\
\text { Fraction }\end{array}$ \\
\hline Saponins & $+\mathrm{ve}$ & $++\mathrm{ve}$ & $++\mathrm{ve}$ \\
Tannins & $-\mathrm{ve}$ & $++\mathrm{ve}$ & $+\mathrm{ve}$ \\
Flavonoids & $-\mathrm{ve}$ & $++\mathrm{ve}$ & $+\mathrm{ve}$ \\
Cardiac glycosides & $-\mathrm{ve}$ & $-\mathrm{ve}$ & $-\mathrm{ve}$ \\
Anthraquinones & $+\mathrm{ve}$ & $+\mathrm{ve}$ & $-\mathrm{ve}$ \\
Terpenoids & $+\mathrm{ve}$ & $++\mathrm{ve}$ & $+\mathrm{ve}$ \\
Steroids & $++\mathrm{ve}$ & $+\mathrm{ve}$ & $-\mathrm{ve}$ \\
Alkaloids & $-\mathrm{ve}$ & $+\mathrm{ve}$ & $+\mathrm{ve}$ \\
Phenol & $-\mathrm{ve}$ & $+\mathrm{ve}$ & $+\mathrm{ve}$ \\
\hline
\end{tabular}

Note: ++ve: Abundant, +ve: Present, -ve: Absent 
Table 2. Percentage chemical composition of $S$. occidentalis leaf fractions

\begin{tabular}{|c|c|c|c|c|c|c|}
\hline Sample & \% Alkaloids & $\%$ Flavonoid & $\%$ Saponin & $\%$ Tannin & $\%$ Terpenoid & $\%$ Total Phenol \\
\hline Hexane fraction & 0 & 0 & $1.5 \% \mathrm{w} / \mathrm{w}$ & 0 & $6 \% \mathrm{w} / \mathrm{w}$ & 0 \\
\hline Ethylacetate fraction & $8 \% \mathrm{w} / \mathrm{w}$ & $0.2 \% \mathrm{w} / \mathrm{w}$ & $2.5 \% \mathrm{w} / \mathrm{w}$ & $1 \% \mathrm{w} / \mathrm{w}$ & $7.5 \% \mathrm{w} / \mathrm{w}$ & $0.73 \% \mathrm{w} / \mathrm{w}$ \\
\hline Methanol fraction & $4 \% \mathrm{w} / \mathrm{w}$ & $0.51 \% \mathrm{w} / \mathrm{w}$ & $9.5 \% \mathrm{w} / \mathrm{w}$ & $1.3 \% \mathrm{w} / \mathrm{w}$ & $5.5 \% \mathrm{w} / \mathrm{w}$ & $0.6 \% \mathrm{w} / \mathrm{w}$ \\
\hline
\end{tabular}
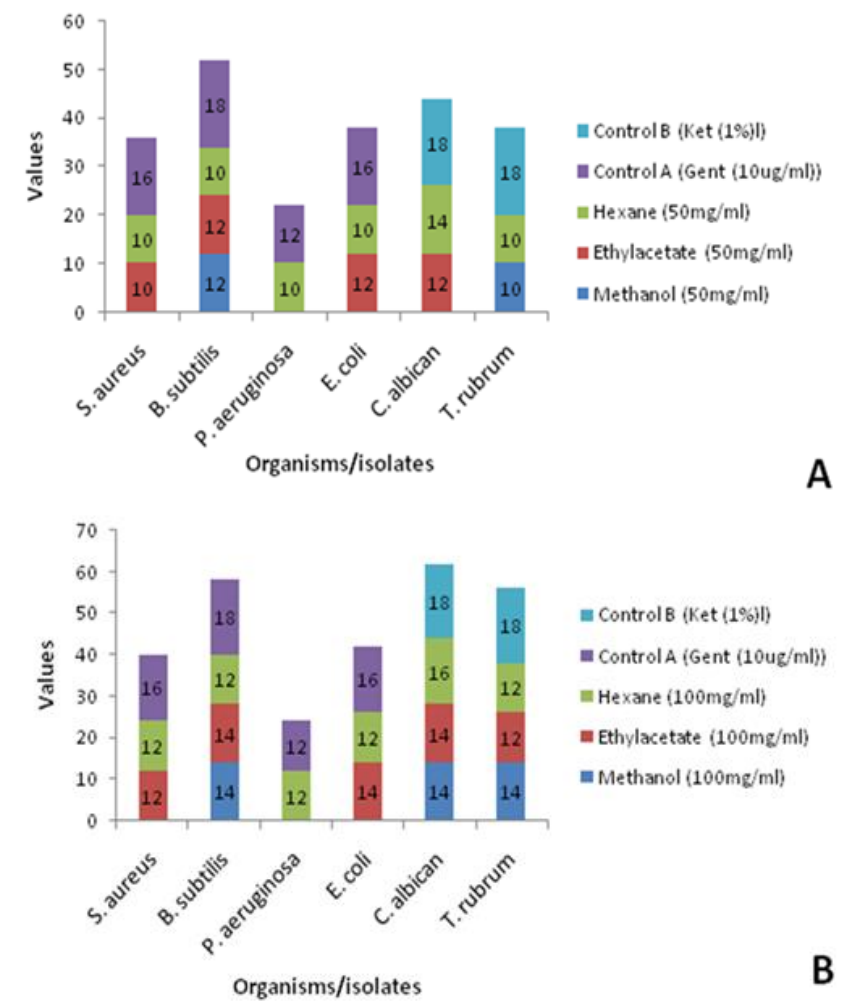

Figure 3. Diameter of inhibitory zone of $S$. occidentalis leaf fractions against several microbes. A. Fraction concentrations of $50 \mathrm{mg} / \mathrm{mL}$; B. Fraction concentrations of $100 \mathrm{mg} / \mathrm{mL}$

Flavonoids and phenols content in ethyl acetate and methanol were low, i.e., $0.2 \% \mathrm{w} / \mathrm{w}, 0.7 \% \mathrm{w} / \mathrm{w}$, and $0.51 \% \mathrm{w} / \mathrm{w}, 0.6 \% \mathrm{w} / \mathrm{w}$ respectively. These results are also supported by previous studies on the flavonoid content of Erythrina velutina $(0.2 \%)$ and Mimosa tenuiflora $(0.21 \%)$, both of the plants that belong to the Fabaceae family, with reported antimicrobial activity in (Siqueira et al. 2012). Also, the low phenol content is similar to the report on stem bark $(0.75 \%)$ and leaves $(0.09 \%)$ of Mangifera indica (Okwu and Ezenagu 2008). Phenols protect plants from oxidative damage and do the same for humans (Okwu 2005).

Tannins content in ethyl acetate and methanol fractions were $1 \% \mathrm{w} / \mathrm{w}$ and $1.3 \% \mathrm{w} / \mathrm{w}$, respectively. Alkaloids were present in ethyl acetate fraction at $8 \% \mathrm{w} / \mathrm{w}$ and methanol at $4 \% \mathrm{w} / \mathrm{w}$. These values are much higher than reported alkaloids in Cucumis sativus (cucumber), and Momordica charantia (bitter melon) leaves with $1.23 \% \mathrm{w} / \mathrm{v}$, where bitter melon ethanolic leaf extract showed $70 \%$ percent inhibition against the E. coli, $S$. dysentariae 1 , and $S$. pneumoniae. In contrast, Cucumis sativus leaf extract was found to have less antibacterial activity (Debnath et al., 2015). The differences in methanol and ethyl acetate could be due to their inherent polarity, influencing their performance.

The antimicrobial activities of $S$. occidentalis against Staphylococcus aureus, Bacillus subtilis, Pseudomonas aeruginosa, Escherichia coli, Candida albicans, and Trichophyton rubrum were examined in this study, and their potency was qualitatively and quantitatively assessed by the presence or absence of inhibitory zones, minimum inhibitory concentration (MIC), and minimum microbicidal concentrations (MMC).

The inhibition zones of the tested fractions against the selected bacterial and fungal strains are shown in Figure 3. in a concentration-dependent manner. The result showed that methanol and ethyl acetate fractions at $100 \mathrm{mg} / \mathrm{mL}$ and $50 \mathrm{mg} / \mathrm{mL}$ did not inhibit the growth of Pseudomonas aeruginosa. However, an inhibitory zone of $12 \mathrm{~mm}$ was observed for both the hexane fraction and the tested control (Gentamicin) at $100 \mathrm{mg} / \mathrm{mL}$ and $10 \mu \mathrm{g} / \mathrm{mL}$, respectively. The zone produced by the standard antibiotic was similar to that produced by the hexane fraction of $S$. occidentalis. Similar to the present work, studies on the antibacterial activity of methanolic leaf extract of Plukenetia conophora against Pseudomonas aeruginosa isolated from urinary tract infection showed a concentration-dependent activity with Pseudomonas aeruginosa having zones of inhibition of $10,12,14$, and $18 \mathrm{~mm}$ at 50,100, 150 and $200 \mathrm{mg} / \mathrm{mL}$ respectively (Enitan et al. 2014).

The methanol fraction did not show any inhibition zone against Staphylococcus aureus and Escherichia coli at $100 \mathrm{mg} / \mathrm{mL}$ and $50 \mathrm{mg} / \mathrm{mL}$ concentrations. The diameter of inhibition of the ethyl acetate and hexane fractions at the concentration of $100 \mathrm{mg} / \mathrm{mL}$ and $50 \mathrm{mg} / \mathrm{mL}$ against Staphylococcus aureus was the same, i.e., $12 \mathrm{~mm}$ and $10 \mathrm{~mm}$, respectively. These values were lower than positive control Gentamicin $(16 \mathrm{~mm})$. A study by Kumar et al. (2010) showed that the inhibitory zone of cardamom extract against $S$. aureus was $6 \mathrm{~mm}$ to $9 \mathrm{~mm}$. The inhibitory zone of hexane, ethyl acetate, and dichloromethane extract against Escherichia coli was 12 $\mathrm{mm}$.

The result showed a similar antibacterial activity of methanol and ethyl acetate fractions at the concentration of $100 \mathrm{mg} / \mathrm{mL}$ against Bacillus subtilis was $14 \mathrm{~mm}$. In contrast, the hexane fraction has an inhibitory zone of $12 \mathrm{~mm}$. These values were lower than Gentamicin's $(18 \mathrm{~mm}$ at $10 \mathrm{ug} / \mathrm{mL})$. The inhibitory zone of hexane fraction against C. albicans at the concentrations of $100 \mathrm{mg} / \mathrm{mL}$ and $50 \mathrm{mg} / \mathrm{mL}$ were $16 \mathrm{~mm}$ and $14 \mathrm{~mm}$. 


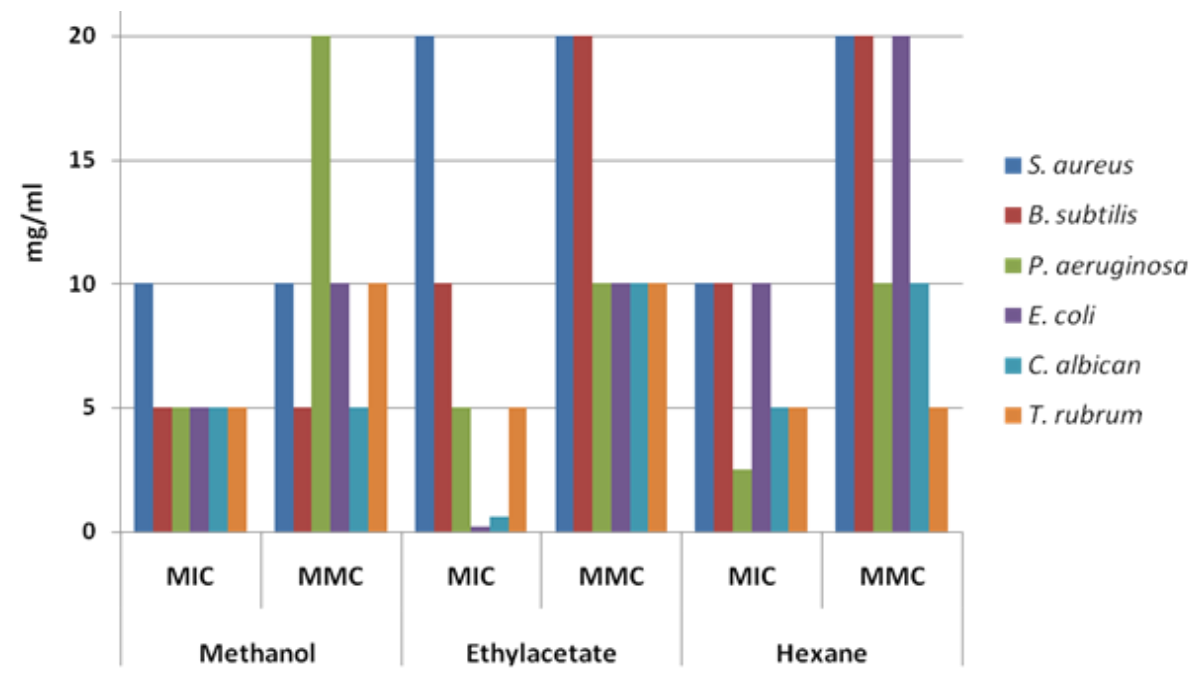

Figure 4. The Minimum Inhibitory Concentration (MIC) and Minimum Microbicidal Concentration (MMC) of S. occidentalis leaf fractions

This fraction has a similar zone of inhibition for all tested bacteria at the concentrations of $100 \mathrm{mg} / \mathrm{mL}$ and 50 $\mathrm{mg} / \mathrm{mL}$, i.e., $12 \mathrm{~mm}$ and $10 \mathrm{~mm}$, respectively. However, these values are much lower than the positive control Ket $1 \%(18 \mathrm{~mm})$. Methanol extract of $S$. occidentalis showed a zone of inhibition of $14 \mathrm{~mm}$ at $100 \mathrm{mg} / \mathrm{mL}$ against Trichophyton rubrum and $12 \mathrm{~mm}$ for ethyl acetate and hexane fractions, respectively, which are lower than that of positive control Ket $1 \%$ (18mm).

The MIC and MMC results of the tested fractions are depicted in Figure 4. Ethyl acetate fraction shows the lowest MIC value of $0.2 \mathrm{mg} / \mathrm{mL}$ and $10 \mathrm{mg} / \mathrm{mL}$ MMC against Escherichia coli. This same fraction also has a MIC value of $0.6 \mathrm{mg} / \mathrm{mL}$ and $10 \mathrm{mg} / \mathrm{mL}$ MMC against Candida albicans. The MIC and MMC values of hexane fractions were $2.5 \mathrm{mg} / \mathrm{mL}$ and $10 \mathrm{mg} / \mathrm{mL}$ against Pseudomonas aeruginosa. The MIC value $(5 \mathrm{mg} / \mathrm{mL})$ of methanol fraction was similar against all tested microbial strains except for Staphylococcus aureus, with the MIC and MMC value of $10 \mathrm{mg} / \mathrm{mL}$. The highest MIC value $(20 \mathrm{mg} / \mathrm{mL})$ was recorded for ethyl acetate fraction against Staphylococcus aureus. The ethyl acetate fraction could be described as having a better antimicrobial activity than other fractions. The results of this study have added to the existing information on S. occidentalis; it is also important to consider its sustainability. On the distribution of $S$. occidentalis, the species seem to be more abundant around the transitional equatorial states in Nigeria (Oyo, Ogun, Lagos, Kwara, Osun, Edo, Ekiti, Ondo, Rivers, etc.) and less in the Northern regions. Hence, its natural habitats need some attention to ensure their sustainable collection and use.

In conclusion, the phytochemical analysis of the leaves of Senna occidentalis shows the presence of flavonoids, tannins, and phenols and the abundance of alkaloids, saponins, and terpenoids. Antimicrobial activities of the $S$. occidentalis fractions were more potent against the tested fungi, Candida albicans, and Trichophyton rubrum, than Gram-positive and Gram-negative bacteria. These results could be used as scientific evidence of the use of the plant as a source of remedy for various ailments traditionally. Further pharmacognostic studies are suggested to ascertain its potency in treating diseases.

\section{REFERENCES}

Ajaib M, Almas M, Khan KM, Perveen S, Shah S. 2016. Phytochemical screening, antimicrobial and antioxidant activities of Ficus natalensis. J Chem Soc Pak 38 (2): 345-351.

Ajayi AO, Akintola TA. 2010. Evaluation of antibacterial activity of some medicinal plants on common enteric food-borne pathogens. Afr J Microbiol Res 4 (4): 314-316.

Akinyemi KO, Oluwa OK, Omomigbehin EO. 2006. Antimicrobial activity of crude extracts of three medicinal plants used in southwest Nigerian folk medicine on some food-borne bacterial pathogens. Afr J Tradit Complement Altern Med 3 (4): 13-22. DOI: 10.4314/ajtcam.v3i4.31173

Arya V, Yadav S, Kumar S, Yadav JP. 2011. Antioxidant activity of organic and aqueous leaf extracts of Cassia occidentalis L. in relation to their phenolic content. Nat Prod Res 25 (15): 1473-1479. DOI: 10.1080/14786419.2010.545351

Barbosa-Ferreira M, Dagli ML, Maiorka PC, Górniak SL. 2005. Subacute intoxication by Senna occidentalis seeds in rats. Food Chem Toxicol 43 (4): 497-503. DOI: 10.1016/j.fct.2004.11.017

Bekele G, Reddy PR. 2015. Ethnobotanical study of medicinal plants used to treat human ailments by Guji Oromo tribes in Abaya District, Borana, Oromia, Ethiopia. Universal J Plant Sci 3 (1): 1-8. DOI: 10.13189/ujps.2015.030101.

Brahmkshatriya PP, Brahmkshatriya PS. 2013. Terpenes: Chemistry, biological role, and therapeutic applications. In: Ramawat K, Mérillon JM. (eds) Natural Products. Springer, Berlin, Heidelberg. DOI: 10.1007/978-3-642-22144-6_120.

Chang CC, Yang MH, Wen HM, Chern JC. 2002. Estimation of total flavonoid content in propolis by two complementary colorimetric methods. J Food Drug Anal 5 (2): 46-52. DOI: 10.38212/22246614.2748 .

Cowan MM. 1999. Plant products as antimicrobial agents. Clin Microbiol Rev 12: 564-582. DOI: 10.1128/CMR.12.4.564

Cushnie TPT, Cushnie B, Lamb AJ. 2014. Alkaloids: an overview of their antibacterial, antibiotic-enhancing and antivirulence activities. Intl $\mathbf{J}$ Antimicrob Agents 44: 377-386. DOI: 10.1016/j.ijantimicag.2014.06.001

Daniyan SY, Oloruntimelehin JB, Ifeadi O. 2011. Antibacterial activity of Cassia occidentalis flower vegetable extract on selected bacteria. Asian J Biomed Pharm Sci 1 (1). DOI:10.15272/AJBPS.V1I1.5. 
Debnath B, Uddin MJ, Patari P, Das M, Maiti D, Manna K. 2015. Estimation of alkaloids and phenolics of five edible cucurbitaceous plants and their antibacterial activity. Intl J Pharm Pharm Sci 7 (12): 223-227.

Enitan SS, Olley M, Uhunmwangho SE, Akele YR, Ehiaghe AF, Enitan CB. 2014. Antibacterial activity of methanolic leaf extract of Plukenetia conophora Mull. arg. against selected bacteria isolated from urinary tract infection. Intl J Microbiol Appl 1 (1): 1-10.

Ejikeme C, Ezeonu CS, Eboatu AN. 2014. Determination of physical and phytochemical constituents of some tropical timbers indigenous to Niger delta area of Nigeria. Eur Sci J 10 (18): 247-270.

Ezeonu CS, Ejikeme CM. 2016. Qualitative and quantitative determination of phytochemical contents of indigenous Nigerian softwoods. New J Sci. DOI: 10.1155/2016/5601327

Gebrelibanos M, Periyasamy G, Sintayehu B. 2014. Senna occidentalis seed: is it health risk or potential medicine? Intl J Pharm 1 (3): 161167.

Gogtay NJ, Bhatt HA, Dalvi SS, Kshirsagar NA. 2002. The use and safety of non-allopathic Indian medicines. Drug Saf 25: 1005-1019. DOI: 10.2165/00002018-200225140-00003.

Haraguchi M, Górniak SL, Calore EE, Cavaliere MJ, Raspantini PC, Calore NM, Dagli ML. 1998. Muscle degeneration in chicks caused by Senna occidentalis seeds. Avian Pathol 27 (4): 346-351. DOI: 10.1080/03079459808419350.

Harborne JB. 1973. Phytochemical Methods: A Guide to Modern Techniques of Plant Analysis. Chapman and Hall, London, UK. DOI: 10.1007/978-94-009-5921-7_1.

Holmgren PK, Keuken W, Schofield EK. 1990. Index Herbariorum Part I. The Habaria of the World. 8th ed. Reg. Veg., New York.

Ibrahim MA, Aliyu AB, Sallau AB, Bashir M, Yunusa I, Umar TS. 2010 Senna occidentalis leaf extract possesses antitrypanosomal activity and ameliorates trypanosome-induced anemia and organ damage. Pharm Res 2 (3): 175. DOI: 10.4103/0974-8490.65513.

Indumathi C, Durgadevi G, Nithyavani S, Gayathri PK. 2014. Estimation of terpenoid content and its antimicrobial property in Enicostemma litorrale. Intl J Chem Tech Res 6 (9): 4264-4267.

Jaeger R, Cuny E. 2016. Terpenoids with special pharmacological significance: A review. Nat Prod Commun 11 (9): 1934578X1601100946. DOI: 10.1177/1934578X1601100946.

Jahan N, Afaque SH, Khan NA, Ahmad G, Ansari AA. 2008. Physicochemical studies of the gum acacia.

Kumar R, Yadav BR, Singh RS. 2010. Genetic determinants of antibiotic resistance in Staphylococcus aureus isolates from milk of mastitic crossbred cattle. Curr Microbiol 60 (5): 379-386. DOI: 10.1007/s00284-009-9553-1.

Laxmi V, Singour PK, Chaurasiya PK, Rajak H, Pawar RS, Patil UK. 2010. Effect of ethanolic extract of Cassia occidentalis Linn. for the management of alloxan-induced diabetic rats. Pharm Res 2 (3): 132137. DOI: $10.4103 / 0974-8490.65506$.

Malik SK, Ahmad M, Khan F. 2017. Qualitative and quantitative estimation of terpenoid contents in some important plants of Punjab, Pakistan. Pak J Sci 69 (2): 150-154.

Miean KH, Mohamed S. 2001. Flavonoid (myricetin, quercetin, kaempferol, luteolin, and apigenin) content of edible tropical plants. J Agric Food Chem 49 (6): 3106-3112. DOI: 10.1021/jf000892m

Nethathe BB, Ndip RN. 2011. Bioactivity of Hydnora africana on selected bacterial pathogens: Preliminary phytochemical screening. Afr J Microbiol Res 5 (18): 2820-2826. DOI: 10.5897/AJMR11.566

Nok AJ. 2002. Azaanthraquinone inhibits respiration and in vitro growth of long slender bloodstream forms of Trypanosoma congolense. Cell
Biochem Funct: Cell Biochem Its Modulation Active Agents Dis 20 (3): 205-212. DOI: $10.1002 / \mathrm{cbf} .948$

Nugroho AE, Malik A, Pramono S. 2013. Total phenolic and flavonoid contents, and in vitro antihypertension activity of purified extract of Indonesian cashew leaves (Anacardium occidentale L.). Intl Food Res J 20 (1): 299-305

Odeja OO, Obi G, Ogwuche CE, Elemike EE, Oderinlo OO. 2014. Phytochemical screening, antioxidant and antimicrobial activities of Senna occidentalis (L.) leaves. Intl J Herbal Med 2 (4): 26-30. DOI: 10.1186/s40816-016-0028-1.

Ogunkunle AT, Ladejobi TA. 2006. Ethnobotanical and phytochemical studies on some species of Senna in Nigeria. Afr J Biotechnol 5 (21): 2020-2023.

Okwu DE, Ezenagu VI. 2008. Evaluation of the phytochemical composition of mango (Mangifera indica Linn) stem bark and leaves. Intl J Chem Sci 6 (2): 705-716.

Okwu DE. 2005. Phytochemicals, vitamins and mineral contents of two Nigerian medicinal plants. Intl J Mol Med Adv Sci 1 (4): 375-381.

Oyekunle MA, Aiyelaagbe OO, Fafunso MA. 2006. Evaluation of the antimicrobial activity of saponins extracts of Sorghum bicolor L. Moench. Afr J Biotechnol 5 (23): 2405-2407.

Ribarova F, Atanassova M. 2005. Total phenolics and flavonoids in Bulgarian fruits and vegetables. J Univ Chem Technol Metallurgy 40 (3): 255-260.

Sheikh N, Kumar Y, Misra AK, Pfoze L. 2013. Phytochemical screening to validate the ethnobotanical importance of root tubers of Dioscorea species of Meghalaya, North East India. J Med Plants 1 (6): 62-9.

Shimada T. 2006. Salivary proteins as a defense against dietary tannins. J Chem Ecol 32 (6): 1149-1163. DOI: 10.1007/s10886-006-9077-0.

Singleton VL, Rossi JA. 1965. Colorimetry of total phenolics with phosphomolybdic phosphotungstic acid reagents. Am J Enol Vitic 16 (3): 144-158.

Siqueira CF, Cabral DL, Peixoto Sobrinho TJ, de Amorim EL, de Melo JG, Araújo TA, de Albuquerque UP. 2012. Levels of tannins and flavonoids in medicinal plants: evaluating bioprospecting strategies. Evid-Based Compl Altern Med 2012. DOI: 10.1155/2012/434782.

Tian XR, Feng JT, Ma ZQ, Xie N, Zhang J, Zhang X, Tang HF. 2014. Three new glycosides from the whole plant of Clematis lasiandra Maxim and their cytotoxicity. Phytochem Lett 10: 168-172. DOI: 10.1016/j.phytol.2014.09.004.

Tona L, Mesia K, Ngimbi NP, Chrimwami B, Okond'Ahoka, Cimanga K, Bruyne TD, Apers S, Hermans N, Totte J, Pieters L. 2001. In-vivo antimalarial activity of Cassia occidentalis, Morinda morindoides and Phyllanthus niruri. Ann Tropic Med Parasitol 95 (1): 47-57. DOI: 10.1080/00034983.2001.11813614.

Uzzi HO, Grillo DB. 2013. The hepatoprotective potentials of aqueous leaf extract of Cassia occidentalis against paracetamol Induced hepatotoxicity in adult Wistar rats. Intl J Herbs and Pharmacol Res 2 (2): 6-13.

Valarmathy K, Gokulakrishnan M, Kausar MS, Paul K. 2010. A study of antimicrobial activity of ethanolic extracts of various plant leaves against selected microbial species. Int J Pharma Sci Res 1 (8): 293295.

Vardhini BV, Anjum NA. 2015. Brassinosteroids make plant life easier under abiotic stresses mainly by modulating major components of antioxidant defense system. Front Environ Sci 2: 67. DOI: 10.3389/fenvs.2014.00067.

Zablotowicz RM, Hoagland RE, Wagner SC. 1996. Effect of saponins on the growth and activity of rhizosphere bacteria. In: Saponins Used in Food and Agriculture. Springer, Boston, MA. DOI: 10.1007/978-14613-0413-5 8. 